\title{
Soft or Hard Power? \\ Discourse Patterns \\ in Brazil's Foreign Policy \\ Toward South America
}

\section{Carola M. Lustig}

\begin{abstract}
This article analyzes the discourse of Brazil's foreign policy toward South America from 1995 to 2010 by means of quantifying, codifying, and weighting all speeches registered in the homogeneous and periodic official documentation of Brazil's Ministry of Foreign Affairs using a discourse analysis approach. The aim is to investigate discourse patterns in order to qualify Brazil's foreign policy as either hard power or soft power and to identify the orientation and differences in its discourse of foreign policy regarding each country of South America during the presidential terms of Fernando Henrique Cardoso (1995-2002) and Luiz Inacio Lula da Silva (2003-2010).
\end{abstract}

B razil's foreign policy has been studied using systemic approaches, qualifying the country alternatively as a midsize power with the ability to promote stability in the global system (Jordaan 2003), as a country with little or no regional leadership (Malamud 2011; Nolte 2010), as a soft power leader (Flemes and Gomes Saraiva 2014; Sotero and Armijo 2007; Gratius 2007), and as a consensual hegemonic leader (Burges 2009) with no material resources to deploy hard power strategies but with the ability to gain the support or recognition of its South American neighbors (Burges 2006, 2009). In short, a benign power (Lafer 2002).

Other studies consider domestic determinants within Brazil's foreign policy. The strength of both the ministerial presence of the left wing in power and the military forces has been included in the research agenda as institutional determinants for the formulation of foreign policy (Amorim Neto 2011). The internationalization of domestic actors in the Brazilian state that actively participate in the formulation of foreign policy produced the rise of Brazil as an international power (Schenoni 2012). Other authors have argued that in order to generate domestic support in favor of the Workers' Party (PT), to the detriment of conservative economic policies, President Luiz Inacio Lula da Silva's strategy was to use diplomacy to associate with Third World and South-South countries during his administration

Carola M. Lustig is an assistant professor of international politics in Latin America at Universidad Católica Argentina and coordinates the area of governmental relations at the PASCAL Program at Universidad Nacional de San Martín. carolamlustig@gmail.com 
(2003-10) (Amorim Neto 2011; Lafer 2006). These articles demonstrate that Brazil's foreign policy is influenced by the ideological orientation of its domestic politics.

More recently, other approaches have combined both perspectives and have evaluated the relative weights of systemic and domestic variables in the foreign policy orientation of three Latin American countries, Argentina, Brazil, and Mexico, using a quantitative indicator, the voting convergence in United Nations General Assembly resolutions (Amorin Neto and Malamud 2015). The authors studied the distribution of capabilities, the degree of trade interdependence, and the government profiles over a large period of time (1946-2008) to identify the factors that best predicted their alignment with the United States. They found that Brazil's foreign policy has a blend of determinants with a prevalence of realist systemic variables.

This study uses another procedure, a discourse analysis approach, and seeks to demonstrate discursive aspects of Brazil's foreign policy toward South American countries between 1995 and 2010. It analyzes speeches of Brazil's foreign policy decisionmakers regarding all the countries in South America during the two presidential terms of Fernando Henrique Cardoso (FHC) and Lula da Silva, with the purpose of qualifying them in terms of soft power-ideational capacities—or hard power-material capabilities - by analyzing speech variations. Hard power means the construction of power based on material resources like military and economic supplies. Soft power means the building of power through ideas, attraction, and seduction. The selection of the period is related to the reorientation of Brazil's foreign policy more strongly toward South America. This reorientation, even if it was formally made in 2000 with the First Summit of South America in Brasília, has been projected and presented before, as shown in the Resenhas de Politica Exterior de Itamaraty, the official documents of Brazil's Ministry of Foreign Affairs. ${ }^{1}$

This article explores the discursive patterns that Brazil has expressed concerning each country of the Andean region, the La Plata River Basin, and the rest of South America, as well as the extent to which these patterns differ or resemble each other. ${ }^{2}$ The objective is to extract new data with the purpose of questioning the commonly accepted hypothesis that Brazil maintains a soft power foreign policy toward South America, at least in its discourse.

Brazil's foreign policy discourse has conserved a constant hard power profile in both the economic and the political dimensions throughout the four presidential terms studied. This trend has occurred regardless of Mercosur's presence, since the dominant discursive profile toward the main country of that organization, Argentina, mostly contains soft power elements. During Fernando Henrique Cardoso's first administration, the discursive profile was more related to hard power matters than that of his second administration and that of Lula's two terms in the presidency, especially in the military dimension. This hypothesis weakens the thesis that affirms that Brazilian foreign policy is a stable public policy, at least in the discourse. Moreover, even when Brazil may be expected to have more conflicts with La Plata River Basin countries, given their historical relations, the outline of its discourse presents more soft power trends and more hard power content toward 
Andean countries during the period studied. This finding may be related to Brazil's increasing concern for protecting the Amazonian region.

This study attempts to contribute to a perspective present in literature that deems that foreign policy is an object of analysis that can adapt to a quantitative treatment (Amorim Neto 2011; Amorim Neto and Malamud 2015) and that can coexist in conjunction with the qualitative tradition of studies of Brazil's foreign policy. In this case, the object of analysis is the discourse of the decisionmakers of Brazilian foreign policy toward South America, from a quantitative perspective.

The article proceeds by presenting a theoretical framework for Brazil's foreign policy. Then it explains the methodological development of the research and makes a conceptual justification for the debate in international relations on hard and soft power. The subsequent section describes the results.

\section{TheORETICAL REVIEW}

Brazil has been characterized and analyzed in many different ways. For the purposes of this study, it is essential to present the theoretical debate about the characteristics of the emerging powers and how they interact with the other countries in the region. This theoretical framework will help to identify Brazil's position in the region as either a soft or a hard power.

\section{Brazil as a Global Player}

The literature that analyzes the rise of regional powers and their relationship with neighboring countries has not agreed on a single definition of the nature of these new powers (Malamud 2011). Some authors have labeled them intermediate powers (Keohane 1969; Hurrell 2000; Jordaan 2003; Soares de Lima and Hirst 2006; Flemes 2007), others as emerging powers (Hurrell 2009; Schirm 2010). Some authors recognize them as midlevel emerging powers or regional powers (Nolte 2010; Lara 2012), others as consensual, hegemonic leaders (Burges 2006, 2009), and still others as leaders without regional followers (Schirm 2010; Malamud 2011).

In the 1960s, Keohane observed that there was a new phenomenon in contemporary international politics associated with the claim of the nonaligned: the emergence in power of small nations. According to Keohane, small states are those that have no hope of influencing the system while acting on their own, but instead need to join forces with other small nations or form alliances through regional or global international organizations (Keohane 1969, 296). According to this definition, Brazil could be considered a medium country seeking support in the region in order to attain its worldwide goals (Malamud 2011, 6).

Hurrell $(2000,1)$ suggests the idea of conceptualizing medium states by the ideas and ideology that have motivated their followers-whether their peers or smaller nations-to accept the legitimacy and authority of a larger nation that is ranked above them in the power hierarchy. What perceptions and viewpoints have motivated the small nations to choose the larger nation as a leader? Under this def- 
inition, Brazil would be an intermediate power if it were able to gain support or recognition from its South American neighbors.

Intermediate powers can be classified as either traditional or emerging. Jordaan (2003) created this classification based on two dimensions: the characteristics that constitute the state and the behavior of the state itself in the international system. In the definition of emerging intermediate powers, Jordaan includes the degree of regional influence the state may have.

A regional power must first possess for itself (self-perception) a position of leadership in a geographical area that is economically, politically, and ideationally circumscribed. The country has to possess material, organizational, and ideological resources with which to project its regional power. It should exert a strong influence in regional affairs and deploy its influence in the geopolitical, political, and ideational construction of the region through a structure of regional governance. It needs to define and promote a common regional identity, promote collective goods, put together the agenda for security in the region, gain its neighbors' acknowledgment in terms of its regional leadership, and represent the interests of the region in global forums (Nolte 2010, 893).

Unlike the United States, China, Russia, and India, Brazil depends on its region (Hurrell 2007; Flemes 2007). Brazil does not wield great power and cannot be expected to be a dominant force in a future global order, due to its lack of material resources_namely, nuclear arms (Flemes 2010, 143). A great power has the capability to contribute to the international order; internal cohesion, capable of making possible the action of an efficient state; economic power, high growth rates, and a large market; and military power with the capacity to compete with other dominant forces (Hurrell 2006). Brazil does not fulfill this last criterion. Thus the variety of strategies for Brazil's foreign policy is limited, forcing the country to rely more heavily on the support of the nations of its region-or on the construction of spaces for consensus and coalitions among midsized powers, such as IBSA (India, Brazil and South Africa) — to be able to carry out soft-balancing strategies. ${ }^{3}$

\section{Brazil as a Regional Player}

The authors mentioned above attempt to give a theoretical response to the dilemma of conceptualizing regional and emerging powers in the international system. Other research has been conducted in the form of case studies of individual countries.

Soares de Lima (2007) indisputably accepts that Brazil is an intermediate power. Bearing this in mind, she analyzes the complexities and the options for foreign policy that holding this status would entail for a country such as Brazil, focusing on three issues: a discussion of interests, power, and influence of the country in terms of its regional role; the regional balance and its relationship with United States; and the tension between the international and the regional challenges and opportunities, on the one hand, and the domestic context, on the other (Soares de Lima 2006, 169). Regarding the difficulties in Brazil's regional coordination, Soares de Lima states that its geographical proximity and its asym- 
metry of size compared to the other nations have ended up generating a syndrome of distrust.

Brazil experienced two different models of foreign policy in the twentieth century (Soares de Lima 2006). One involved a special relationship with the dominant force, and the other was based on obtaining autonomy from the international power structure. Historically, a mutual distrust prevailed between Brazil and Argentina, together with other countries of the La Plata Basin. However, with the end of the dispute with Argentina, the creation of Mercosur, IIRSA (Initiative for the Integration of the Regional Infrastructure of South America), and the South American Community of Nations, advancements have been detected in Brazil's regional inclusion. Despite this shift in Brazil's foreign policy toward recognizing a greater importance of South America, its neighbors did not perceive Brazil as having gained influence and prestige as a regional leader. Spektor (2011) accepts Brazil's regionalism in South America and analyzes it based on three causal factors: material incentives, ideas, and foreign policy. ${ }^{4}$

Only the United States and the European Union expected Brazil to have a more assertive role in the region. Spektor contends that Brazil constantly maintains an ambivalent attitude toward South America.

Three proposals, thus, mark Brazilian thinking on the regional environment: Brazil may enjoy power, prestige and influence in international relations without resulting in its taking on the role of regional supreme power; the region may function as a protective shield of national autonomy in the era of globalization; and the region may function as a launching pad to gain more power, prestige and national influence. Although all three point in different directions, they coexist and fluctuate uncomfortably, helping explain, at least in part, the ambiguity of Brazil's attitude toward South America. (Spektor 2011, 185).

In a forceful article analyzing the failings of Brazilian diplomacy in relation to neighboring countries, Malamud (2011) contends that although Brazilian diplomats thought they should consolidate Brazil as a regional leader as a means to obtain global recognition, Brazilian foreign policy has not given the country the structural and instrumental resources to become the region's leader. Brazil's potential followers did not align with its main interests, such as gaining a permanent seat on the UN Security Council or the general directorship of the WTO. Malamud demonstrates a growing divergence between the accomplishments that Brazil has attained on the global level and those attained at the regional level. In sum, Brazil is a regional leader, but with few followers. Thus Malamud's article questions Brazil's aspirations as a regional leader and states that the country will most probably become a medium-sized global power before it can achieve acceptance at a regional level.

In a similar sense, Caballero (2012) affirms that Brazil has been able to construct a very clear image of success projected abroad, shaping how it relates to other countries, but this model is not consistent with the country's economic plan, nor does it confirm Brazil as a superpower. ${ }^{5}$ Furthermore, Wehner (2015) believes that the expectations of secondary powers (Alter) like Argentina in regard to a regional 
power (Ego) like Brazil are key for the role conception of a state (Wehner 2015, 436) because in the interaction with "Others" are defined all roles, both master and auxiliary. That assignation of roles - social identity to actors—is based on the information Alter has about Ego but also on how the region is delimited. ${ }^{6}$ Therefore, Brazil'master role does not exclusively depend on the state's self-awareness of its predominant material position in South America. It is also about whether or not the actors of the region recognize Brazil as holding a specific status, as well as about whether the secondary powers either favor or hamper its quest for global powerhood (Wehner 2015, 438).

In sum, all the studies contribute to analyzing Brazil's foreign policy using systemic approaches, considering domestic determinants, or both. The literature that analyzes the rise of regional powers and their relationship with neighboring countries has not agreed on a single definition of the nature of this new power. The approaches also have changed depending on how Brazil's attitude toward the international system and toward the regional countries is defined. Generally, Brazil is considered fundamentally a soft power without nuclear weapons and thanks to the absence of strategic enemies with nuclear weapons (Malamud and Rodríguez 2014). This lack of agreement leads us to incorporate into the analysis new aspects of the study of Brazil's foreign policy. Therefore, this article raises the question of what type of discourse Brazil's foreign policy toward South American countries has expressed, attempting to contribute to a different perspective that deems foreign policy an object of analysis, that it can adapt to a quantitative treatment (Amorim Neto 2011; Amorin Neto and Malamud 2015), and that it can coexist in conjunction with the qualitative tradition of analysis of Brazil's foreign policy.

The opportunity will come to analyze in qualitative perspective the results of this discourse analysis. This is not to ignore the different changes that occurred in the regional context, such as the modification in the main purpose of Mercosur (Malamud 2005) and the emergence of the left-leaning governments throughout Latin America, the so-called Pink Tide (Amorin Neto and Malamud 2015). Mercosur has increased the level of political rhetoric since the crises of 1998-99, but no concurrent deepening in effective policy implementation has taken place. This can explain some results of the analysis. Also, the left turn of the governments throughout Latin America may explain some new tendencies of the discourse after 2002. The objective of this article is simply to give another empirical source and analytical perspective for classifying Brazilian foreign policy. In order to advance in the analysis is important to explore the conceptualization of hard and soft power. 


\section{Methodological AND CONCEPTUAL EXPLANATION}

The article has two separate contributions. The first is to include discursive analysis in the investigation of foreign policy in Latin America, and for this case, to question the commonly accepted hypothesis that Brazil maintains a soft power foreign policy toward South America, at least in its discourse. The second contribution is to operationalize the concept of soft and hard power. The discourses set forth in the Resenhas de Politica Exterior de Itamaraty are political texts, an important and accessible source of empirical evidence on the discursive patterns of the foreign policy of Brazil, since political causes are defended in political speeches, party platforms, and electoral programs (Alonso et al. 2012, 11). ${ }^{7}$ In addition, since all the texts are official, comprehensive, and homogeneous sources, they can be analyzed objectively, systematically, and completely without making their selection biased or random.

The discourse analysis technique used here is based on the Manifiesto Project, which analyzes the content of political texts to identify political party preferences and ideological positions as stated in party platforms. ${ }^{8}$ This study selected all the speeches that appeared in every semiannual report from 1995 to 2010 in which the orators either mentioned or traveled to a South American country. This universe amounted to 357 speeches broken down according to presidential terms and by year. ${ }^{9}$

Analyzing the content of political texts required three steps (Alonso et al. 2012). First, code units were extracted from the texts. The code units were quasiphrases or nuclear phrases, key words in context selected for each variable. ${ }^{10}$ Second, the frequency with which each code unit appeared for each variable was counted, reaching a total of 4,500 quasi-phrases. Third, an index of hard and soft power was built and analyzed according to the different semantic nodes selected. With this speech analysis, the study attempted to detect patterns in mentions-quasiphrases - and arrange them according to different dimensions constituting the concept of hard and soft power. Thus the profile of Brazil's foreign policy speeches regarding South America could be qualified.

For the purposes of this study - and in order to carry out a specific operationalization for this research - the concepts of hard and soft power were measured by using three radial dimensions each. The concept of hard power contains the military dimension, the economic dimension, and the political dimension. The concept of soft power contains the migration dimension, the education dimension, and the sociocultural dimension. For each of these dimensions, 4 variables were selected, totaling 24 variables, as shown in table 1 . Each of the variables was assigned a weight in order to create a scale between hard ( 1 to 0$)$ and soft power $(0$ to -1$)$ in Brazil's foreign policy.

Also, for each of the previously numbered variables, a set of quasi-phrases was established to identify the presence of each dimension in each speech. The online appendix itemizes the quasi-phrases that were selected in order to detect the presence of variables in each of the dimensions that make up hard and soft power and their corresponding weighting to obtain the hard-soft gradation index or scale. ${ }^{11}$ 


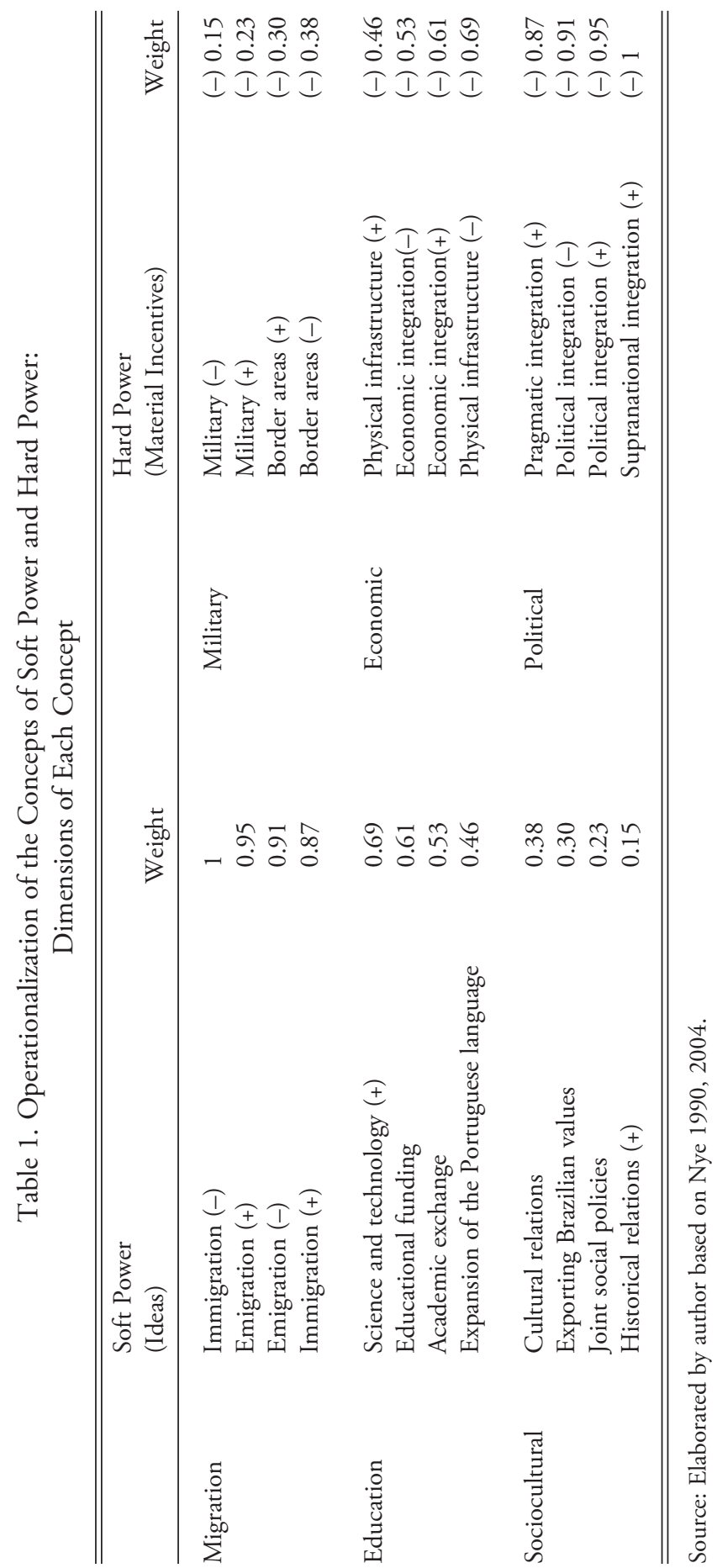


For the operationalization of hard and soft power, I follow the conceptualization of Joseph Nye, who uses the generic concept of power to define hard power and soft power in Bound to Lead (1990). In this work, Nye explains the difficulty of defining the notion of power by comparing it to that of love: both are easy to experience yet hard to define. "Power is the ability to get others to do what they otherwise would not do" (Nye 1990,26). That ability relies on ideational power, material resources, or a combination of both.

\section{Ideational Power versus Material Resources}

Nye states that in order to measure the effectiveness of power, one would have to know the preferences of another country to determine whether there was concrete influence from one nation to another that would explain the change of behavior. Power always depends on the context in which the relationship takes place (Nye 1990). Thus, this behavioral definition of power makes it almost impossible to measure.

This is why diplomats and political leaders associate power with the possession of certain resources-population, land, natural resources, the size of the economy, military forces, and political stability_all which can be measured (Nye 1990). The most powerful state would be the one with the greatest resources with which to exert coercion and pressure through economic sanctions. Thus, an initial definition of hard power is "the ability to affect the behavior of others in order to obtain what one wants through the use of coercion and payments" (Nye 2009a, 160).

But are large states - those with many resources—always powerful? Not all heads of state of large nations have turned their nations into powerful units. Leaders need to know how to turn resources into power. This is where leadership enters into play. "Converting resources into realized power in the sense of obtaining desired outcomes requires well-designed strategies and skillful leadership" (Nye 2004, 3). It is precisely the concept of leadership that allows us to identify the difference between hard and soft power. Legitimacy in the exercise of power is equivalent to leadership, and the lack of legitimacy leads to coercion. Power, thus, is the capacity to convert resources into effective influence in any context.

Nye (2004) affirms that soft power contains resources that can produce a change in the behavior of other nations that might feel an ambition to attain those assets, whether material or symbolic. Some resources are able to produce both soft and hard power. The well-known metaphor of the carrot and the stick may illustrate the difference between soft power and hard power. The stick represents the (fearful) consequences of failing to comply (with some established rule). Conversely, the carrot creates incentives where the stick (fear of retaliation) is not effective or may have an elevated cost. These are two different ways of using different costs and consequences either to compel or to coerce others to behave the way we desire.

For instance, a strong economy may produce effective payments (carrots) with which to exert influence or pressure on other countries, but may also serve to show 
itself as a successful model of development that attracts others (Nye 2009b, 18), and may represent an incentive to follow that country.

Resources that produce soft power emerge from a positive estimation that some countries construct concerning the culture of another country. This type of power mostly rests on three resources: culture (in the characteristics that are attractive to others), political values (when countries abide by the same values domestically as internationally), and foreign policy (when the nation is seen as a moral, legitimate authority) (Nye 2009b, 19).

The difference seems to reside in power defined in terms of resources and power judged in terms of changes in behavior. The problem lies in the inability to measure how power affects behavior. In fact, Javier Noya has criticized Nye's dualist theory, claiming that "soft power is not a type of power but in fact any resourceincluding military capacity - may be soft as long as it is socially legitimized for a specific purpose. This means that perception becomes a key element" (Noya 2005, 3).

Economic and military resources may help both to attract and to coerce (Gelb 2009). This means that many different types of resources may contribute to increasing soft power (e.g., attractiveness). While soft power is not synonymous with direct influence, it does serve as a source of influence. Influence can also emerge from the hard power of threats and payments, however (Nye 2009a).

The main difference between these two types of powers is that there are occasions when leaders are able to accomplish what they want without issuing rewards or threats. This soft power co-opts instead of coercing. The distinction between the two is a question of degree as a continuum variable, both in the nature of the behavior and in the tangibility of the resources. Behavior types include pure attraction, determining the agenda, and inducing certain behavior through economic measures and coercion. The degree of tangibility of the resources ranges from admiration for the values of a nation to payment or finally, sanctions and deployment of military forces. Both types of power are important. Attracting others, suggesting items for the agenda, forcing changes through threats, and economic or military sanctions are all relevant in order to "get others to aspire to what one aspires to" (Nye 2004, 30). However, pure attraction and the values and culture of a society that is capable of seducing another society are always intangible.

For this reason, this study attempts to operationalize these concepts and acknowledge that it is a question of gradation. The gradation scale is constructed on two concepts. Soft power is the power that allows a nation to accomplish its goals in international affairs through attraction (carrots) rather than coercion (sticks). Hard power lies in the ability to generate both incentives (carrots) and threats (sticks) simultaneously. 


\section{Results of THE STUdy}

The debate is still ongoing regarding the elements of continuity and rupture of Brazil's foreign policy toward South America during the administrations of Fernando Henrique Cardoso (FHC) and Luiz Inácio Lula da Silva (Lula). Authors like Amado Cervo (2002), Alcides Costa Vaz (2004), and Cristina Pecequilo (2008) believe that there was continuity. A second group, including Vigevani and Ramanzini (2009), Paulo Roberto de Almeida (2004), and Luiz Souto Maior (Couto 2004, 26), assert that there was a turning point during FHC's second administration that took on a more critical stance toward globalization and the FTAA, given international financial instability, the collapse of Argentina, and the September 11 attacks (Vizentini 2005, 381). Other authors point to a change in the foreign policy toward South America not during FHC's terms but during those of Lula.

Brazil's foreign policy during the FHC era has been qualified as having "neither sticks nor carrots" (Burges 2006) —in other words, predominantly soft or with a consensus-seeking leadership style due to Brazil's historical aversion to direct, visible coercion, and because of the Itamaraty project to construct a geopolitical and geoeconomic entity in the post-Cold War scenario (Burges 2006, 24), capable of creating a unified position within the international system.

This work presumes that foreign policy is a public policy, and as such, speeches are an essential part of it. By detecting diverse patterns or quasi-phrases present in the speeches and assigning them to the dimensions studied, I quantified, codified, and measured them through an index constructed so that a graduation in speech profile from hard to soft power could be established. It was not my goal to measure the influence of Brazil on neighboring countries but rather to qualify the discourse of the foreign policy by analyzing the reports and identifying core phrases present in identifiable texts.

Based on the analysis of speeches delivered by government agents who formulated Brazil's foreign policy during the entire period, as well as how they have been codified and indexed according to the operationalization of the concepts of hard and soft power, two premises can be discussed: the continuity and the soft nature of Brazil's foreign policy during the four presidential terms.

Figure 1 shows, for each dimension, the sum of the semiannual average weighted for the two concepts of hard and soft power constructing the index. The distribution curve of the values reveals the presence of a continuum in the discursive profile of Brazil's foreign policy for the entire period. This assertion is corroborated by the relatively stable behavior of the curve that expresses the historical tendency of the index $\left(\log x^{2}\right)$, with the exception of FHC's first term. Similarly, the constant presence of hard content can be confirmed, with an exception in 2007.

In order to confirm the hypothesis regarding whether Brazil's foreign policy toward South America remained steady or changed during the four presidential terms studied, the biannual values were calculated once more, but this time adding up the averages per speech instead of using the dimensions of the index. Results displayed in figure 2 are consistent with those analyzed in figure 1 and strongly corrob- 
Figure 1. Hard-Soft Index of Speeches on Brazil's Foreign Policy Toward Latin America (1995-2010)

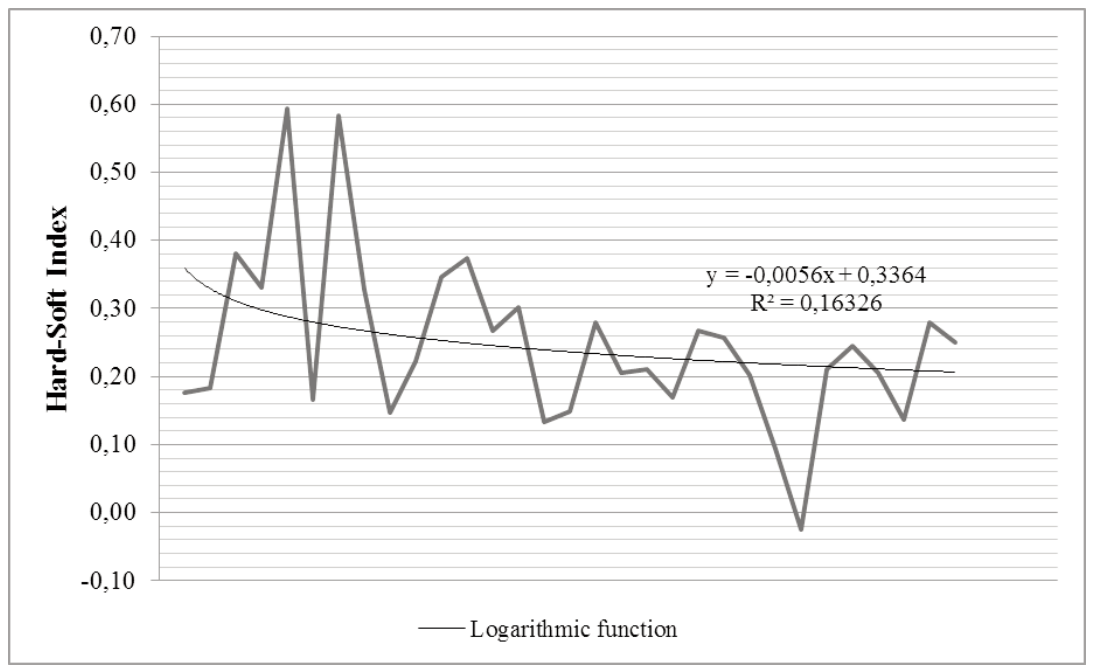

Source: Compiled by the author based on codifying, weighting, and indexing of speeches in Itamaraty foreign policy reports

orate that speeches delivered by government officials who shape foreign policy contained predominantly hard power references, and that this occurred constantly over the four presidential terms.

However, on more detailed analysis of the hard content in foreign policy speeches, two observations can be substantiated. First, figures 3 and 4 exhibit a difference-not between the FHC and Lula administrations regarding South America, but between FCH's first and second terms. In fact, during FHC's first term (199598), Brazil's speech on foreign policy regarding the region had more element of hard power than it did in successive terms, including FHC's second term (1998-2002) and Lula's two terms. The change in foreign policy related to South America is already evident in FHC's second term, eliminating the hypothesis that there the vision changed only after Lula took office.

Furthermore, figures 3 and 4 reveal that although there is continuity in the vision of South America within Brazil's foreign policy discourse between FHC's second term and Lula's first, the content of the hard element does indeed change. During Lula's administration, there are fewer elements related to hard content connected to the military dimension and more hard elements connected to the economic dimension, possibly due to the need for physical infrastructure in the South American region.

Similarly, as mentioned earlier, the main innovation in South American politics during the Lula administration was the emphasis on the political dimension of for- 
Figure 2. Hard and Soft Content in Speeches on Brazil's Foreign Policy Toward Latin America (1995-2010)

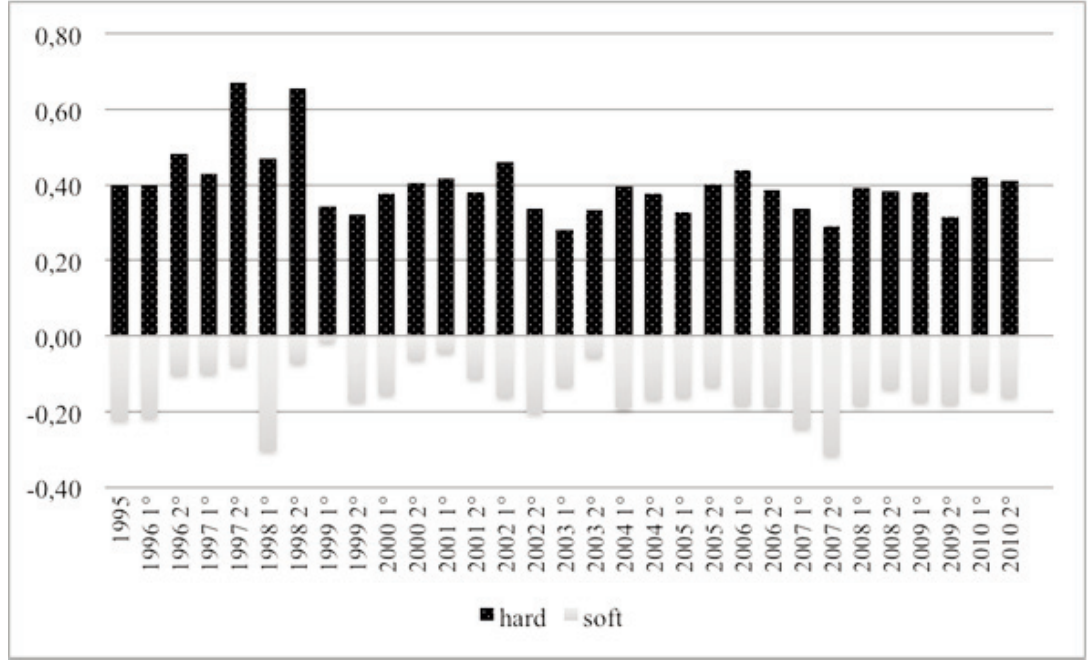

Source: Compiled by the author based on Itamaraty foreign policy reports

eign policy (Soares de Lima 2007, 180), which also included social issues as the most important concern of foreign policy (Soares de Lima and Hirst 2006, 22). In fact, figure 3 shows that the sociocultural dimension is predominant in the soft profile of government officials' speeches.

However, if we continue to break down hard and soft contents in the speeches, as well as in their behavior in each dimension, new data may come to light. Figure 5 shows that discourse content tends to behave differently. The hard content of foreign policy tends to drop, while the soft content tends to increase. This may partially confirm the literature's hypothesis that Brazil's foreign policy is a policy of soft power, or that at the very least, it is in its discourse. With the aim of identifying the trend of each dimension in the discourses of Brazil's foreign policy, it is notable that the sociocultural and military dimensions tend to decrease while the economic, political, and educational dimensions tend to rise.

Based on the data analyzed, Brazil's foreign policy shows continuity in the discursive profile toward South America between the FHC administration and that of Lula. Similarly, the change in the discursive profile occurs between FHC's first and second terms and not between two different administrations with different party affiliations and ideological identifications. This also could imply that Brazil's foreign policy could be a constant state policy that does not change with the alternation of the ruling party, political leadership, or different ideologies, at least in the discourse.

The discourse of Brazil's foreign policy is predominantly hard but tending to diminish, while its soft content has the same pattern of behavior but is less percep- 
Figure 3. Hard and Soft Content by Dimension in Speeches on Brazil's Foreign Policy Toward Latin America (1995-2010)

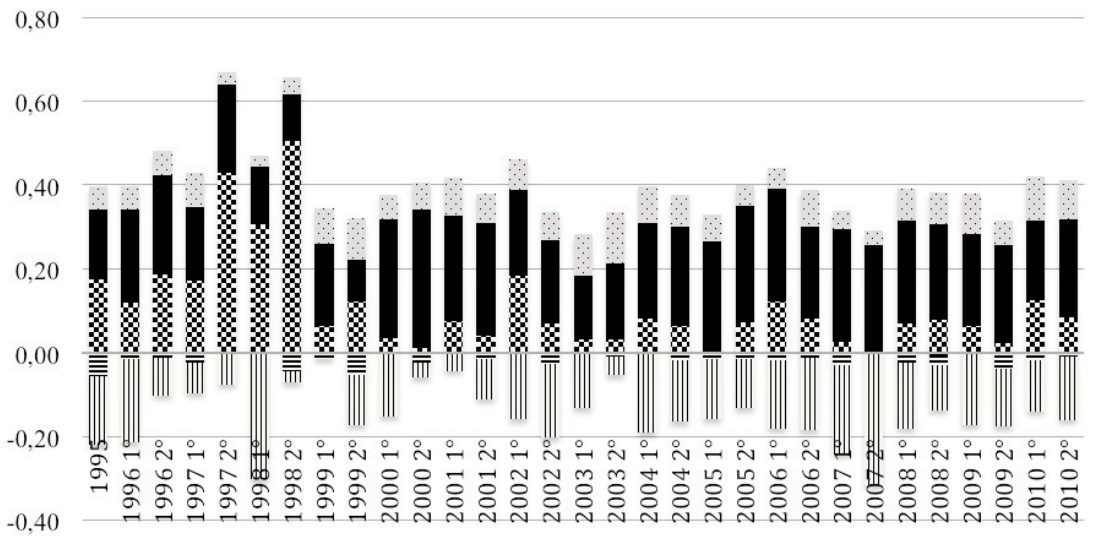

* Military Dimension

- Migration Dimension
Economic Dimension

$\equiv$ Education Dimension $\because$ Political Dimension

III Sociocultural Dimension

Source: Compiled by author based on Itamaraty foreign policy records

Figure 4. Trends in Each Concept in Speeches on Brazil's Foreign Policy Toward Latin America (1995-2010)

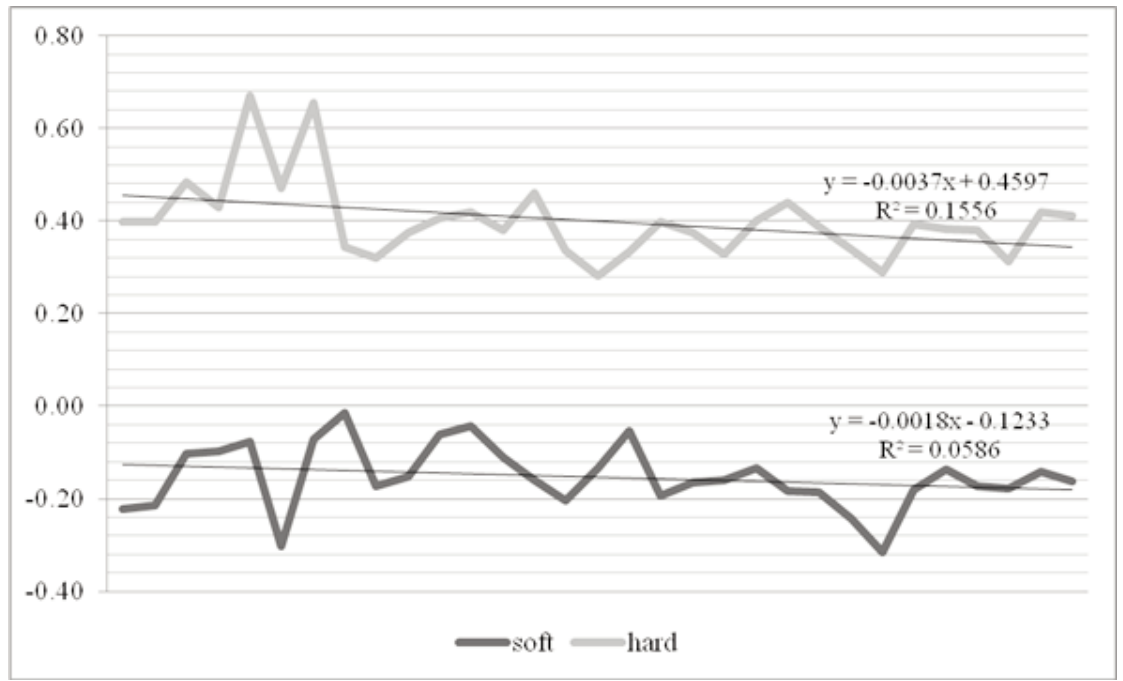

Source: Compiled by author based on Itamaraty foreign policy records 
Figure 5. Trends in All Dimensions for the Entire Period

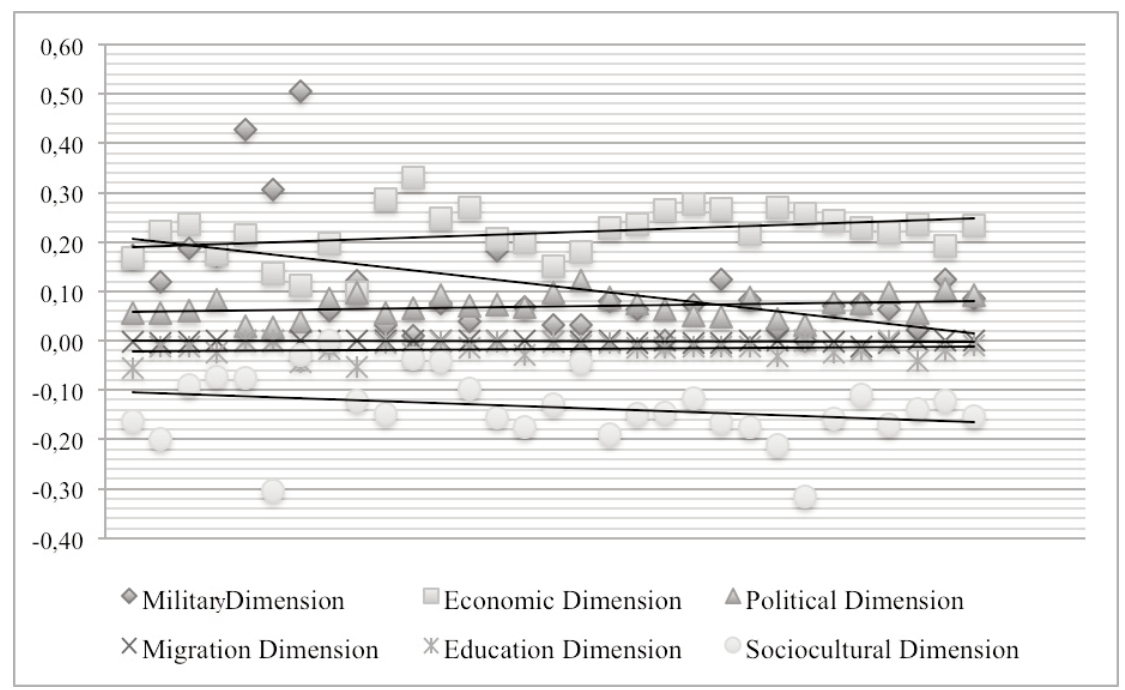

Source: Compiled by the author based on Itamaraty foreign policy records

tible. Within the hard content, it may be stated that the military elements of discourse, which are the majority for FHC's first term, give way to content that is more economic and political in nature from FHC's second term on. Within the soft profile in foreign policy discourse, the sociocultural dimension is predominant, yet tends to diminish during Lula's second term.

On the other hand, if we analyze each conglomerate separately by country, the previous observation is reinforced (figure 6). In the case of the Andean countries, the hard-soft index increases greatly toward the hard dimensions, starting with Lula's first term. Figure 7 shows that the variation in the discourse is much more abrupt from this point on. During the FHC administrations, all mentions of the Andean region have predominantly soft components. If we observe the La Plata River Basin conglomerate by taking each country separately (figure 8), the discourse has predominantly hard components during the FHC administrations, with a slight tendency to diminish during Lula's administrations.

Therefore it is essential to mention the difference between how Brazil has historically related to countries in the north and south of the South American continent. Brazil has increased political and economic relations with southern countries, particularly after ending disputes with Argentina, starting the bilateral cooperation program in 1986, and subsequently founding Mercosur in 1991 (Soares de Lima 2007). Seeing the type of relationship that Brazil has with the countries of the La Plata River Basin may lead one to presuppose that the discourse of Brazil's foreign policy toward this particular conglomerate of nations - with which it has a free trade 
Figure 6. Trends in Hard-Soft Index in Speeches on Brazil's Foreign Policy Toward La Plata River Basin and Andean Nations for the Entire Period

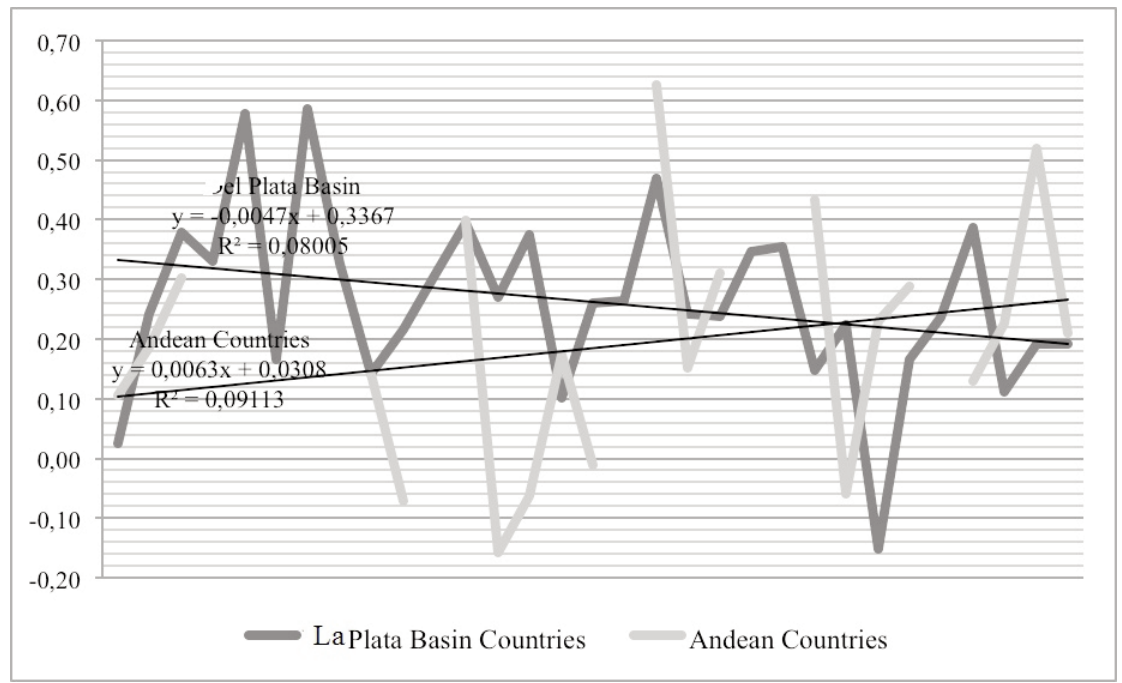

Source: Compiled by author based on Itamaraty foreign policy records

Figure 7. Trends in Hard-Soft Index in Speeches on Brazil's Foreign Policy Toward Peru, Venezuela, Ecuador, Chile, and Colombia for the Entire Period

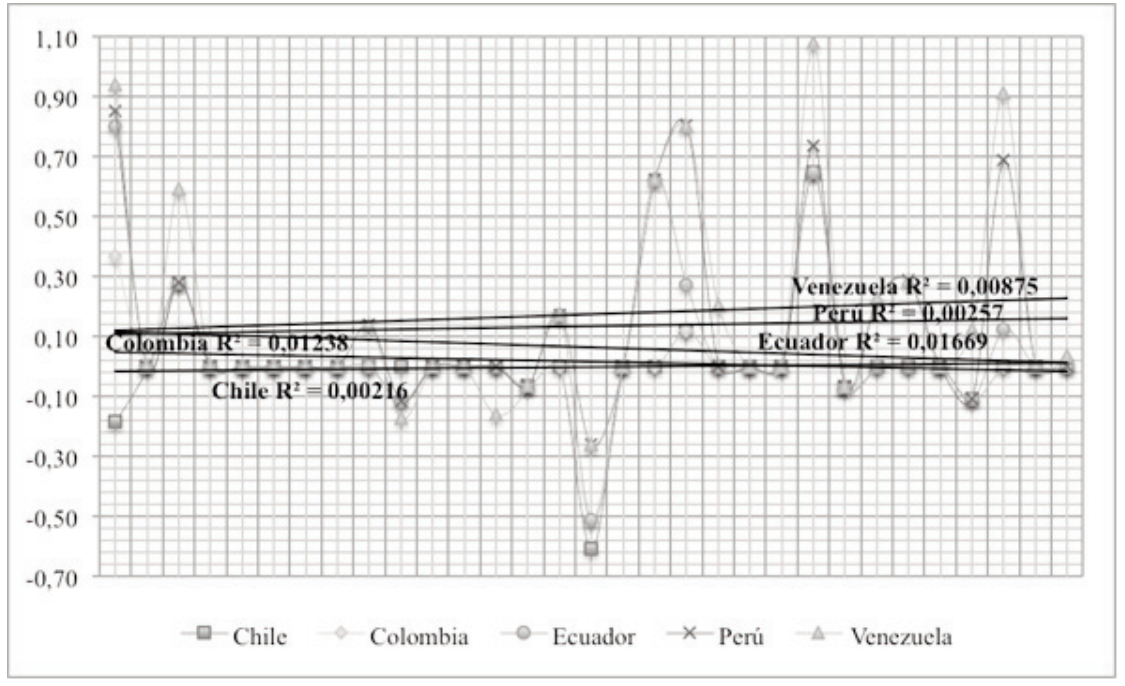

Source: Compiled by author based on Itamaraty foreign policy records 
Figure 8. Trends in Hard-Soft Index in Speeches on Brazil's Foreign Policy Toward Argentina, Bolivia, Uruguay, and Paraguay

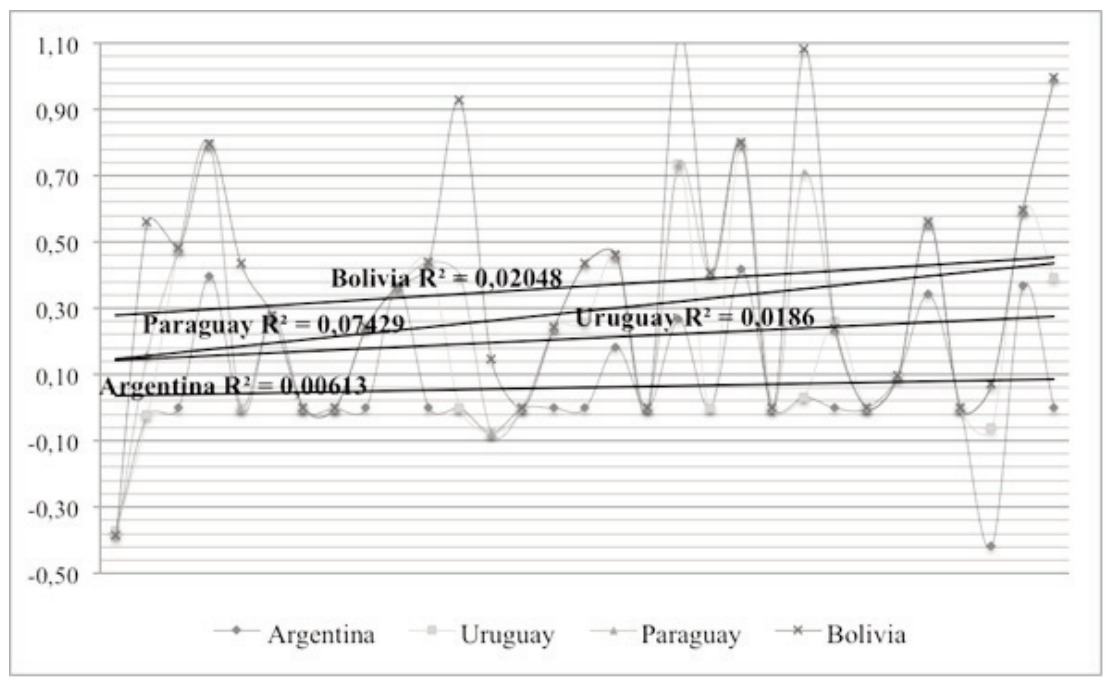

Source: Compiled by author based on Itamaraty foreign policy records

zone-would probably be closer to hard power than the discourse about Andean countries because of the economic dimension related to hard power.

However, although it is true that Brazil's discursive profile regarding the La Plata Basin nations is closer to hard power at the beginning of the period studied, this tends to decline markedly during the Lula administration. Therefore the existence of Mercosur has not led to a Brazilian discourse of hard power toward those countries. The third hypothesis of this study, then, is not confirmed.

This study has helped to identify the differences in discursive patterns of Brazil that occurred regarding South America in each presidential term. During FHC's first term, the hardest discursive profile is toward Bolivia, Colombia, Ecuador, and Uruguay. The softest discursive profile of the foreign policy is with Argentina, Paraguay, and Peru. During his second term, this pattern changes slightly, given that Bolivia, Uruguay, and Paraguay occupy a hard position during this period. Later with Argentina, Ecuador, and Peru, Brazil takes a position in its discourse that is between hard and soft power, although tending toward hard power. In contrast, the foreign policy discourse of Brazil is soft regarding Chile, Colombia, and Venezuela during the second term.

During the Lula administration, foreign policy becomes less hard, especially for countries that make up the La Plata River Basin. Lula's first term displays a tendency to homogenize its positions toward South American countries in its foreign policy. Nevertheless it is possible to establish some differences, given that the dis- 
cursive behavior of Brazil's foreign policy related to Bolivia, Ecuador, Paraguay, Peru, and Uruguay has more contents of hard power than it does in relation to Argentina, Chile, and Colombia. This may be due to the increased support during Lula's first term for infrastructure projects and IIRSA financing for regional integration of physical infrastructure, launched under FHC's administration but buttressed during Lula's two terms, particularly thanks to funding from the Brazilian Development Bank.

\section{Conclusions}

Studies on Brazil's foreign policy have proliferated in the last three decades, shedding light on the "South Americanization" of foreign policy. The flipside of this change in orientation is the role that the South American behemoth plays in the developing South American regional strategies. According to some authors (Flemes and Wehner 2013), the central role that South America now has for Brazil has not translated into the production of collective goods for the countries of the region. Moreover, Brazil has restricted itself to granting the minimum public goods to serve its own national interests: the construction of collective defense and investment in physical infrastructure.

Brazil's interest in the South American region-along with the structural asymmetry that sets it apart from the rest of the region's nations-revives certain fears of Brazilian hegemony, fueled by some nations' domestic political decisions (Soares de Lima 2007). Several strategic movements occur among South American countries that are not linear or capable of being analyzed from a single perspective. Nevertheless, in this context, the literature has qualified the type of foreign policy in Brazil as that of soft power.

This article offers a new empirical approach to the behavior of the discourse in Brazil's foreign policy regarding the region of South America during the administrations of FHC and Lula by quantifying and analyzing the content of political texts; that is, speeches included in the Itamaraty report on foreign policy. Although the results are circumscribed by a historical period corresponding to four presidential terms and a specified territory, they represent a change in orientation toward the region in Brazil's foreign policy. Additionally, the operationalization of the concepts of soft and hard power has never before been discussed in the literature. The operationalization of these terms, as well as the creation of the index, may allow generalizations.

In this research, the terms hard and soft power were defined as a strategy of radial conceptualization. The concept of hard power was specified through three dimensions: military, economic, and political. The concept of soft power was specified through three dimensions: migratory, educational, and sociocultural. In order to better identify the quasi-phrases to detect in every speech analyzed and to have a more finely tuned measure for each dimension, each one was divided into four variables. Each variable was weighted in such a way that a gradation index was created between hard power and soft power. 
The data show that Brazil's foreign policy is a stable policy and, as such, has a behavior that does not change to a great extent. Thus, from FHC's first term to Lula's final term, the behavior of Brazil's foreign policy was constant within a hard discourse pattern regarding South America. This hard component of the discourse shows a slight tendency to diminish, while the soft component of the discourse tended to rise, especially after Lula took office. The first conclusion of this research is that Brazil's foreign policy has a continuous discursive behavior. The second conclusion is that this continuous discursive behavior is predominantly hard, with a tendency to increase in the soft component.

The conclusion about the stability of foreign policy discourse was strengthened by another observation that resulted from this study: the data show that changes in the foreign policy discourse do not happen when there is a change in administration, but rather when there is a change in the international political and economic context. We may identify a shift not from FHC's second term to Lula's first but earlier, between FHC's first and second terms, after 1998. Thus, the third conclusion extracted from this study is that the stability in Brazil's foreign policy discourse may not depend on domestic conditions connected to the political party in power.

This general conclusion is interesting, given the wide range of existing studies that ascertain a relationship between domestic conditions and the evolution of foreign policy. In this case, evidence shows that changes in the discursive profile of a foreign policy do not depend on domestic conditions, or at least do not depend on the party affiliation or ideology of whoever is in power, but seem to respond to systemic issues.

In addition, in light of certain generalizations that can be made as to the type of foreign policy that Brazil carries out regarding South America, the data presented throughout the study provide evidence that the region cannot be considered a homogeneous entity and a single, unified object of analysis. Accordingly, this study analyzed the discursive behavior of Brazil's foreign policy by organizing the South American region by conglomerates, and later by individual countries.

\section{NoTES}

1. South America's becoming a priority area for Brazil is a recent phenomenon. The presence of such a concept ("South America") dates back to 2000, when, to counterbalance the U.S. advance with its proposed creation of the Free Trade Area of the Americas and failures within the framework of Mercosur, Brazil created its own area of influence, explicitly leaving out Mexico and Central America. At that time, the perception was already present that regional integration would be fundamental for Brazil to play its global role. However, already in 1995, on the occasion of a trip to Venezuela, FHC had said, "For us Brazilians, regional integration advanced as Mercosur and today is projected for the other countries of South America and from there to the hemisphere. Mercosur begins to identify new partners in South America, where we are negotiating approaches with Venezuela, Chile, Bolivia, in addition to the entire set of the Andean Pact" (Cardoso 1995).

2. The aggregation La Plata River Basin includes five countries: Brazil, Argentina, Paraguay, Uruguay, and Bolivia. 
3. The concept of soft-balancing represents one of two ways in which balance of power manifests itself. The theory of balance of power is the cornerstone of realist theory in international relations. It is based on four main premises: the international system is anarchistic, and states have no authority to protect themselves; states constantly seek to survive as independent entities; competing for power is a given in international politics; when one state dominates, the remaining states that feel threatened will form defensive coalitions or will acquire military equipment to protect themselves. Thus, strategies of soft balancing may be defined as those opposing hard-balancing strategies. The latter are based on putting together collective alliances and accumulating weapons that would compensate a state's power of primacy at the systemic level, while soft-balancing strategies entail forming diplomatic coalitions, especially in the United Nations.

4. Spektor posits that there are four material factors that can explain the change of direction in the Brazilian foreign policy regarding the region: the priority of controlling inflation, the regionalization of the Brazilian economy and the interdependence that stems from it, the logic of trade negotiations in the FTAA, and the progressive shift of U.S. attention away from the region.

As far as ideas are concerned, Spektor considers two great beliefs present in the decisionmaking circles of Brazil. First, the construction of the concept of South America was designed by Brazil with the goal of protecting itself from the contagion effect of the Tequila crisis coming from Mexico, the U.S. ambition to expand the FTAA throughout the South American continent, and Argentina's 2001 economic crisis. Mexico has close ties to the United States, no national development project of its own, and suffered the Tequila crisis. Argentina was weakened by the 2001 crisis that consequently dismantled Mercosur as an economic space. Consequently, Brazil decided to expand Mercosur with the explicit purpose of diluting Argentina's relative power in the bloc. Second, Brazil's elites and diplomats consider that the definition of power in international relations never meant greater involvement with the region. In fact, Brazilian decisionmakers have always understood the mechanism of power in Latin America as one of regional balance of power and not "bandwagoning."

5. "Although ideas and images have the ability, in a way, to invoke realities and signify concepts, we must ponder whether under the discursive façade constructed in Brasília, there truly is an emerging power that can back up words with actions. This is not to imply that the image is false but rather that it has been constructed thanks to amplifying certain elements, while attempting to conceal other less favorable ones." (Caballero 2012, 81)

6. Wehner (2015) analyzes the expectations of three countries in South America, Argentina, Chile, and Venezuela, in terms of what kind of roles they attribute to Brazil, depending on the differing notions of region. For example, Argentina gives Brazil a leading role in Latin America, including Mexico, but not in South America. Chile attributes to Brazil a leading role in Latin America and as a global power. Venezuela expects Brazil to have a leading role in South America but not in Latin America because the Caribbean countries are Venezuela's own area of influence.

7. This diplomatic documentation consists of two reports per year, containing speeches delivered by Brazil's main government officials who participate in foreign policy; namely, the president of the republic, the vice president of the republic, the state minister of foreign affairs, and the secretary-general.

8. The Manifesto Project was created in the 1970s to compare party program strategies in the United Kingdom and the United States after World War II. The procedure began with a selection of relevant texts-electoral platforms - which then were broken down into differ- 
ent units of analysis. Once the Manifesto Project researchers had constructed a classification scheme, they codified each text.

9. 1995 (24 speeches), 1996 (44), 1997 (9), 1998 (12), 1999 (13), 2000 (19), 2001 (30), 2002 (29), 2003 (27), 2004 (29), 2005 (18), 2006 (28), 2007 (16), 2008 (20), 2009 (19), 2010 (20).

10. According to Alonso et al. (2012), the choice of isolated words as codification units may be problematic because there are many ways to address an issue. Therefore all possible variations must be analyzed within contextual units that are broader than those to which the words belong (key words in context, KWIC).

11. The Index of Hard-Soft Power is built as $\sum$ Frequency of appearance * weighted value / total number of appearances. The weighting for each variable corresponding to the concept of hard was assigned a number between 1 and 0 , where 1 represents more elements of a hard power foreign policy and 0 represents fewer elements. The weighting for each variable of the concept of soft power falls between 0 and -1 , where the softest discourse profile of foreign policy will be represented by -1 and the least soft will be represented by 0 . Between four and ten core phrases correspond to each variable. The index of foreign policy type was constructed as the summation of the appearance of these core phrases multiplied by their weighting, divided by the number of total appearances, and was calculated year after year so as to show a progression in the degree of intensity of Brazil's foreign policy. The gradation scale is constructed on two concepts. Soft power is the power that allows a nation to accomplish its goals in international affairs through attraction (carrots) rather than coercion (sticks). Hard power lies in the ability to generate both incentives (carrots) and threats (sticks) simultaneously.

\section{REFERENCES}

Almeida, Paulo Roberto de. 2004. Uma política externa engajada: a diplomacia do governo Lula. Revista Brasileira de Politica Internacional 47, 1: 162-84.

Alonso, Sonia, Andrea Volkens, and Bráulio Gómez. 2012. Análisis de contenido de textos políticos. Un enfoque cuantitativo. Colección Cuadernos Metodológicos 47. Madrid: Centro de Investigaciones Sociológicas.

Amorim Neto, Octavio. 2011. De Dutra a Lula. A condução e os determinantes da política externa brasileira. Rio de Janeiro: Elsevier.

Amorim Neto, Octavio, and Andrés Malamud. 2015. What Determines Foreign Policy in Latin America? Systemic versus Domestic Factors in Argentina, Brazil, and Mexico, 1946-2008. Latin American Politics and Society 57, 4 (Winter): 1-27.

Burges, Sean W. 2006. Without Sticks or Carrots: Brazilian Leadership in South America During the Cardoso Era, 1992-2003. Bulletin of Latin American Research 25, 1: 23-42. . 2009. Brazilian Foreign Policy After the Cold War. Gainesville: University Press of Florida.

Caballero Santos, Sergio. 2012. Brasil y su imagen. Anuario Americanista Europeo 2221-3872, 10: $53-72$.

Cardoso, Fernando Henrique. 1995. Speech by the President of the Republic at the session of Congress of Venezuela, Caracas, July 4. Resenha da Politica Exterior 77, 2nd semester.

Cervo, Amado Luiz. 2002. Relaçôes internacionais do Brasil: um balanço da era FHC. Revista Brasileira de Politica Internacional 45, 1: 5-35.

Couto Gonçalves, Cláudio. 2004. El gobierno de Lula en busca de un rumbo. Revista América Latina Hoy 37: 17-38. 
Flemes, Daniel. 2007. Emerging Middle Power's Soft Balancing Strategy: State and Perspectives of the IBSA Dialogue Forum. Giga Working Paper 57. http://dx.doi.org/10.2139/ ssrn.1007692.

- 2010. O Brasil na iniciativa BRIC: soft balancing numa ordem global em mudança? Revista Brasileira de Politica Internacional 53, 1: 141-56.

Flemes, Daniel, and Leslie Wehner. 2013. Reacciones estratégicas en Sudamérica ante el ascenso de Brasil. Foreign Affairs Latinoamérica 13, 4: 107-14.

Flemes, Daniel, and Miriam Gomes Saraiva. 2014. Emerging Powers in the Network Order: The Case of Brazil. Revista Brasileira de Politica Internacional 57, 2: 214-32.

Gelb, Leslie H. 2009. Power Rules: How Common Sense Can Rescue American Foreign Policy. New York: Harper Collins.

Gratius, Susanne. 2007. Brasil en las Américas. ¿Una potencia regional pacificadora? Documentos de Trabajo de FRIDE. http://fride.org/download/WP35_BraAmer_ESP_ abr07.pdf

Hurrell, Andrew. 2000. Some Reflections on the Role of Intermediate Powers in International Institutions. In Paths to Power: Foreign Policy Strategies of Intermediate States, ed. Hurrell, Andrew F. Cooper, Guadalupe González González, Ricardo Ubiraci Sennes, and Srini Sitaraman. Washington, DC: Woodrow Wilson International Center. 1-10.

—. 2006. Hegemony, Liberalism and Global Order: What Space for Would-Be Great Powers? International Affairs 82, 1: 1-19.

- 2007. One World? Many Worlds? The Place of Regions in the Study of International Society. International Affairs 83, 1: 127-46.

- 2009. Brasil y la tormenta que se avecina. Foreign Affairs Latinoamérica 9, 2: 43-54.

Jordaan, Eduard. 2003. The Concept of a Middle Power in International Relations: Distinguishing Between Emerging and Traditional Middle Powers. Politikon: South African Journal of Political Studies 30, 2: 165-81.

Keohane, Robert O. 1969. Lilliputian Dilemmas: Small States in International Politics. International Organization 23, 2: 291-310.

Lafer, Celso. 2002. La identidad internacional de Brasil. 1st ed. Buenos Aires: Fondo de Cultura Económica.

Lara, Ignacio. 2012. Potencialidades y límites de Brasil como potencia media emergente. Anuario Americanista Europeo 2221-3872, 10: 53-72.

Malamud, Andrés. 2005. Mercosur Turns 15: Between Rising Rhetoric and Declining Achievement. Cambridge Review of International Affairs 18, 3 (October): 421-36.

— 2011. A Leader Without Followers? The Growing Divergence Between the Regional and Global Performance of Brazilian Foreign Policy. Latin American Politics and Society 53, 3 (Fall): 1-24.

Malamud, Andrés, and Julio C. Rodríguez. 2014. A caballo entre la región y el mundo. El dualismo creciente de la política exterior brasileña. Desarrollo Económico-Revista de Ciencias Sociales 54, 212 (May-August): 63-78.

Nolte, Detlef. 2010. How to Compare Regional Powers: Analytical Concepts and Research Topics. Review of International Studies 36, 4: 881-901.

Noya, Javier. 2005. El poder simbólico de las naciones. Working paper 35. Madrid: Real Instituto Elcano. http://www.realinstitutoelcano.org/wps/portal/rielcano/Imprimir? WCM_GLOBAL_CONTEXT=/elcano/Elcano_es/Zonas_es/DT35-2005

Nye, Joseph. 1990. Bound to Lead: The Changing Nature of American Power. New York: Basic Books. 
2004. Soft Power: The Means to Success in World Politics. New York: Public Affairs. 2009a. Get Smart. Foreign Affairs 88, 4: 160-63.

2009b. Hard Decisions on Soft Power: Opportunities and Difficulties for Chinese Soft Power. Harvard International Review 31, 2 (Summer): 18-25.

Pecequilo, Cristina Soreanu. 2008. A política externa do Brasil no século xxi: os eixos combinados de cooperação horizontal e vertical. Revista Brasileria de Política Internacional 51, 2: 136-56.

Schenoni, Luis Leandro. 2012. As possíveis causas domésticas da liderança brasileira na América do Sul. Revista Contexto Internacional 34, 2: 659-91.

Schirm, Stefan. 2010. Leaders in Need of Followers: Emerging Powers in Global Governance. European Journal of International Relations 16, 2: 197-221.

Soares de Lima, María Regina. 2007. Brasil como país intermedio: imprecisión conceptual y dilemas políticos. In India, Brasil y Sudáfrica: el impacto de las nuevas potencias regionales, ed. Juan Gabriel Tokatlian. Buenos Aires: Libros del Zorzal. 169-90.

Soares de Lima, Maria Regina, and Mónica Hirst. 2006. Brazil as an Intermediate State and Regional Power: Action, Choice and Responsibilities. International Affairs 82, 1: 21-40.

Sotero, Paul, and Leslie Elliot Armijo. 2007. Brazil: To Be or Not to Be a BRIC. Asian Perspectives 31, 4: 43-70.

Spektor, Matías. 2011. El regionalismo de Brasil. In Brasil y América del Sur: miradas cruzadas, ed. Bernardo Sorj and Sergio Fausto. Buenos Aires: Catálogos. 161-98.

Vaz, Alcides Costa. 2004. Brazilian Foreign Policy Under Lula: Change or Continuity? Friedrich-Ebert-Stiftung Briefing Paper. www.fes.de

Vigevani, Tullo, and Haroldo Ramanzini. 2009. Brasil en el centro de la integración. Los cambios internacionales y su influencia en la percepción brasileña en la integración. Revista Nueva Sociedad no. 219 (January-February): 76-96.

Vizentini, Paulo Fagundes. 2005. De FHC a Lula. Uma década de política externa (19952005). Revista de Ciências Sociais 5, 2: 381-97.

Wehner, Leslie E. 2015. Role Expectations as Foreign Policy: South American Secondary Powers' Expectations of Brazil as a Regional Power. Foreign Policy Analysis 11, 4: 43555.

\section{SUPPORTING INFORMATION}

Additional supporting materials may be found with the online version of this article at the publisher's website:

1. Online appendix

For replication data, see the author's file on the Harvard Dataverse website:

https://dataverse.harvard.edu/dataverse/laps

Base Datos Resenhas PEB 1995-2010 